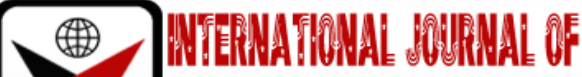

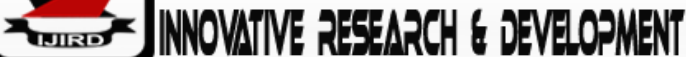

ISSN 2278-0211 (Online)

\section{Assessment of the Effects of Stress and Age on Decision to Commit Suicide among Male Police Officers at Tabora Region, Tanzania}

\author{
Kimbute Meba Msuya \\ Police Officer, Department of Tanzania Police School, Tanzania Police Force, Tanzania
}

\begin{abstract}
:
Decision to commit suicide is one of the most prevalent problems among male police officers. The study aimed at assessing the effects of stress and age on decision to commit suicide among male police officers at Tabora region. 262 Survey were conveniently distributed to male police officers in Tabora region. The information collected was analyzed using descriptive statistics and multiple linear regressions. The findings indicated that both age and stress have statistically significant effects on the decision to commit suicide among police officers. The study recommends that the government should consider police problems and priorities to enable them work with passions despite the danger of the work. There should be more training to police officers, chief officers but the supervisors need to know how to handle matters in their duties so that they can reduce stress among each other.
\end{abstract}

Keywords: Stress, age, suicide, male police officers

\section{Introduction}

Evidence suggests that exposure to law enforcement work is associated with increase in many forms of stress (Song, et al., 2010) including physical, psychosocial, and anticipatory stress (Violanti, et al., 2016; Zhao, et al.,2002; Anderson, et al.,2001). Officers are exposed to traumatic calls for service on a daily basis, including child abuse, domestic violence, car crashes, and homicides. Repeated exposure to these stressors and events worldwide may be associated with development of mental illnesses, such as anxiety, depression, somatisation, posttraumatic stress disorder (PTSD), and burnout (Jetelina, et al.,2020; Komarovskaya, et al., 2011; Maguen, et al., 2009; Gershon, et al., 2008; Liberman, et al., 2002 and Gershon, et al., 2002).

In USA, Officer Suicide Statistics, (2019) stated on retired Detroit police officers over a period of 35 years that broken down on a per-year basis, the crude suicide rate was actually lower among Detroit police retirees than the white male general population (9.8/100,000 vs. 31.5/100,000 respectively). Integrating stress associated with police work into officers' daily social lives prepared them for a resilient separation free from the residuals of posttraumatic stress and depression (Violanti, et al., 2011). Cumulative duty-related trauma exposure poorly predicted PTSD symptoms in separated police officers (Harvey, et al., 2017). There were generally no differences in the quality of life in retired Illinois State Police officers, regardless of the retirement option chosen. Former officers were generally more satisfied with their jobs than current officers (Health and Safety Executive, 2016).

It is often assumed that in Africa retired or separated officers are more likely than current working officers to commit suicide (Health and Safety Executive, 2008). This assumption is based on proposed separation anxiety factors which may lead officers to a state of isolation, depression, and potential suicide (Office for National Statistics, 2014). Deschamps, et al., (2003) described this as the membrane effect, where a network of trusted, close persons served to protect persons from distress. Cherry, et al., (2006) found associations between the police career and post-separation inactivity, bitterness, and disappointment. Garbarino, et al., (2019) found that 12\% of officers who left police work were dissatisfied with separation, and $40.63 \%$ noted that they missed being a police officer. A study of 1,334 retired male Scottish police officers ( $34-94$ years old) found that officers were increasingly susceptible to depression (Garbarino, et al., 2019).

Organizational stressors in East Africa suggested to contribute to the manifestation of stress include lack of support and heavy work load (Kop, et al., 2016), interpersonal conflict with colleagues and supervisors (Luceño-Moreno, et al., 2016) inadequate resources, time pressure, and an overly bureaucratic organizational system, punitive of staff and strictly managed (Luceño-Moreno, et al., 2016; Brough and Biggs, 2010). These findings likely seem to hold over crosscultural comparisons cross the UK, USA, South Africa and other foreign police agencies (Kirkcaldy, Cooper and Ruffalo, 2015; Kirkcaldy,et al., 2015; Alexander, et al., 2014; Brown and Campbell, 2010). Within the existing evidence base the stress outcomes commonly demonstrating or suggested to be associated with organizational stressors in police officers are occupational stress, anxiety, depression, burnout, psychiatric symptoms (PS)/psychological distress (PD)and suicidal 
ideation (Kim, et al., 2016; Oweke, Muola and Ngumi, 2014; Husain, 2014; McCafferty and McCafferty, 2012; Marchand and Durand, 2011; Liberman, et al., 2002).

In Tanzania, an issue of suicidal cases among police officers occurs more frequently than people thinks. The current statistics indicates that in 2019, around 49police officers committed suicide, where the significant percent were male. Regional wise, Tabora among other regions is the region with more suicide cases among police officers. For example, eight male police officers committed suicide in 2018, eleven male police officers committed suicide in 2019, and fifteen male police officers committed suicide in 2020 (URT, 2019). The existing current status indicates that the information collected regarding officer suicide is either not collected or departments are reluctant to allow general public to have access to such data (Jetelina, et al., 2020). In addition, police suicides may be misclassified routinely as either accidents or undetermined deaths (Kapade-Nikam and Shaikh, 2014). Because police officers traditionally subscribe to a myth of indestructibility, they view suicide as particularly disgraceful to the victim officer and to the profession (Galanis, et al., 2019). Based on this information, therefore this study specifically intended to identify factors influencing decision to commit suicide among male police officers at Tabora region. It further examined the effect of stress on decision to commit suicide among male police officers at Tabora region. In the end, the study examined the influence of age on decision to commit suicide among male police officers at Tabora region. This study is very important especially now the country is in the process of utilizing the police force to assist peace and unity in the country. If causes of suicide rates among male police officers are known, then it would be easy to control that problem and the government would be in a position to save lives of energetic citizens. Additionally, this study came at the right time that the police officers are in military training sessions therefore it would be nice to control suicidal problems among police officers so that the government trainings would not be wasted.

\section{Literature Review}

The study will be guided by interpersonal theory of suicide. The interpersonal theory of suicide attempts to explain why individuals engage in suicidal behavior and to identify individuals who are at risk. The theory consists of three components that together lead to suicide attempts. According to the theory, the simultaneous presence of thwarted belongingness and perceived burdensomeness produce the desire for suicide. While the desire for suicide is necessary, it alone will not result in death by suicide. Rather, Joiner asserts that one must also have acquired capability (that is, the acquired ability) to overcome one's natural fear of death.

\subsection{Relationship between Stress and Decision Commit Suicide among Police Officers}

Strong evidence of significant associations was identified for organizational stressors and the outcomes of: occupational stress, psychiatric symptoms/psychological distress, emotional exhaustion and personal accomplishment. The organizational stressors most often demonstrating consistently significant associations with mental health outcomes included lack of support, demand, job pressure, administrative/ organizational pressure and long working-hours (Purba and Demou, 2019). Suicide is common in all societies caused by multiple social or moral pathologies of society. The paper also tries to unveil the incidents of spatial variability of suicides from a socio-geographical standpoint, citing examples from India (Karmakar, 2014). Participants' problem-solving and assistance pursuit coping styles were shown as important mediating factors for stress and subjective well-being, especially positive affect. These findings need to be considered when planning interventions and implementing strategies focusing on the psychosocial health of the improvement of police officers' well-being (Ryu, Yang and Choi, 2020).

\subsection{Relationship between Age and Decision Commit Suicide among Police Officers}

Danger was a factor when examining stress. Administration support was found to be a source of support (Kenwright, 2008). Majority of suicides in working officers occur in the five years just prior to retirement eligibility, suggesting a period of decision anxiety. Results suggest a higher risk of suicide among working compared to separated/retired officers. However, the need for suicide prevention efforts remains important among both active and retired police officers (Violanti, et al., 2011).

\section{Methodology}

The study was undertaken using primary data police officers located in different police stations in Tabora region. Tabora Region has a record of having eight male police officers who committed suicide in 2018, eleven male police officers who committed suicide in 2019, fifteen male police officers who committed suicide in 2020. Tabora region is selected because it is among the regions which have a record of male police officers to committee suicide(RE0, 2019).262 questionnaires were collected conveniently from various police offices in Tabora.The collected data was analyzed using binary logit regression analysis while the respondent's demographic information was analyzed using descriptive statistics. Before analyzing the information, assumptions of linearity, Homoscedasticity, outliers and normality assumptions were tested. Reliability of the data was tested using cronbach alpha and validity of the instruments were also tested using pilot study.

\section{Findings}

\subsection{Respondent Characteristics}

The findings indicated that $45 \%$ were female while 55\%were male whereby most of the respondents' range between the age of 35 and 50 years. The maximum age was represented by $8.7 \%$ of the respondent, minimum was 35,38 
and 45 were only $1 \%$ of the respondents. Most of the respondents were those with families and they have covered the largest percent of the respondents. It was observed that most of the respondent in the study acquired an education level of Bachelor Degree. 93\% of the respondents acquired bachelor degree while the remaining 7\% of the respondents acquired master degree.72.5\% are married while $27.5 \%$ are single therefore, most of the police officers have engaged themselves in marriage as they have more responsibility to think of including work issues and family issues than those who are not married. $97 \%$ of the respondents have long military experience as they have been working for more than three years in the military while the remaining $3 \%$ of the respondents have been working less than three years in the military. $96 \%$ of the respondents are the police officers, $3 \%$ of the respondents are the inspectorate and the remaining $1 \%$ of the remaining respondents are the police gazzeted officers. Findings of the study indicate that most of the respondents are the rank and files as their police rank and the fewest rank are the police gazzeted officers.

\subsection{Reliability}

Internal consistency of the research instrument used Cronbach's Alpha.Cronbach's Alpha is a reliability coefficient that indicates how well items in a set are positively correlated to one another (Sekaran, 2006). According to Bryman and Bell (2015), generally reliability of 0.7 to 1.0 is considered acceptable. Cronbach's Alpha that was less than 0.6 will be generally considered to be poor, those which was 0.7 will be acceptable and those over 0.8 is good; the closer the reliability coefficient gets to 1.0 the better. Result of internal reliability test in Table 1 indicates that a Cronbach in this study was $0.806,0.799$ and 0.813 as represented below.

\begin{tabular}{|c|c|c|}
\hline S/N & ITEM & CronbachAlpha \\
\hline $\mathbf{1}$ & Age & 0.806 \\
\hline $\mathbf{2}$ & Stress & 0.799 \\
\hline $\mathbf{3}$ & Decision to commit suicide & 0.813 \\
\hline \multicolumn{2}{|c|}{ Table 1: Reliability Testing } \\
\hline
\end{tabular}

\subsection{Relationship between Stress and Decision to Commit Suicide}

The study intended to find out the relationship between the effect of stress and decision to commit suicide among male police officers. Therefore, to test the influence of relationship between the effects of stress on decision to commit suicide among male police office

With regards to relationship between stress and decision to commit suicide, blames from chief officers is one of the relationships between the effects of stress in decision to commit suicide. The results were statistically significant at $\mathrm{p}=$ $0.000, \operatorname{Exp}(B)=0.903$ and a Wald of 0.009 . These results showed that blames from chief officers in effect of stress in decision to commit suicide. Finding further indicated that an increase on the blames from chief officers by 0.009 level, then the odds ratio is 0.016 which implies that blames with high relationship between the effect of stress in decision to commit suicide have high level of allowing stress to the police man.

\begin{tabular}{|c|c|c|c|c|c|c|}
\hline Variables & $\begin{array}{c}\text { Coefficient } \\
\text { (B) }\end{array}$ & S.E. & Wald & Df & Sig. & Exp (B) \\
\hline Blames from chief officers & 0.016 & 0.293 & 0.009 & 1 & 0 & 0.903 \\
\hline Dispute from supervisor & 0.421 & 0.296 & 5.404 & 1 & 0 & 0.507 \\
\hline Dispute from chief officers & 0.81 & 0.433 & 4.923 & 1 & 0.025 & 0.403 \\
\hline $\begin{array}{c}\text { Lack family member to express their } \\
\text { problems }\end{array}$ & 0.786 & 0.564 & 4.987 & 1 & 0.034 & 0.564 \\
\hline Understanding on how tough the job is & 0.987 & 0.567 & 4.798 & 1 & 0.006 & 0.965 \\
\hline Lack of advice & 0.576 & 0.342 & 3.768 & 1 & 0.001 & 0.687 \\
\hline Get tensed & 0.675 & 0.354 & 2.786 & 1 & 0.002 & 0.765 \\
\hline Frustrated of angry & 0.845 & 0.498 & 3.879 & 1 & 0.003 & 0.567 \\
\hline Feeling under pressure & 0.876 & 0.287 & 0.989 & 1 & 0 & 0.678 \\
\hline Felling upset about things & 0.509 & 0.399 & 2.678 & 1 & 0.002 & 0.698 \\
\hline Constant & 8.079 & 2.6 & 9.652 & 1 & 0 & 3225.09 \\
\hline Omnibus Tests of Model Coefficients & & & & 5 & 0.001 & \\
\hline Hosmer\&Lemeshow Test & & & & 9 & 0.453 & \\
\hline
\end{tabular}

Table 2: Relationship between Stress and Decision to Commit Suicide

\section{Discussion}

The findings indicated that most police officers different types of criminal people, some are difficult to handle and dangerous and some are somehow easy to handle. According to the Bureau of Justice Statistics (2013), approximately 1,300 police officers in the United States have been killed since 2002. Most of the police officers have great chances of getting hurt when on duties as they sometimes meet different people who are somehow dangerous to them. On the other hand, Crank, et al., (2015) suggest some individuals accept the job because of the need for a job that does not require a college education and has 'good' pay and benefits. Police officers get injuries when they are in the line of duties or when they at duties in late hours. Traumatic events may consist of the death of a fellow officer, stabbing/shooting incidents, investigating traffic accidents involving injury, viewing murder or suicide victims, violent sexual or physical assault, abuse 
or death of children, or having to inform family members about the death of a loved one (Moher, et al., 2015). Police officers sometimes give compliments when one is underperforming. Unlike the findings, which police officers refer to as the 'Code of Silence,' is endorsed by police officers and their family members (not to exclude close friends). It was discovered that police officers do not report other police officers' personal problems because of a fear of revenge or being 'black-balled' by other police officers (Edwards, 2006). The 'police culture' and 'code of silence' makes it difficult for police officers to admit that they have an alcohol or substance abuse problem. Researchers have indicated that statistical data is hard to find because police officers do their 'suffering' in silence or associate with other police officers who enable the behavior (Violanti et al., 2011). Police officers accept that when things go wrong in their daily duties their chief officer usually blame them as to why things have gone wrong. Ballard and McGlone (2017) suggested that police officers are trained to be problem solvers who have to control their emotions when exposed to traumatic or violent events. The research reflected that police officers will not seek mental health treatment but instead will try to fix their own problem.

Police officers are sometimes worried because when their chief officers have dispute with someone in the fiend the totally act in an unfriendly way which make other police officers who are not involved to suffer. The display of frequent exposure to violence will vary based on the police officers' career longevity and personality (Anshel et al., 2017). Officers in the force usually don't have those people who are close to them to tell them the problem that they are facing at work. This can be because to tell a person your problems, you must trust the person that you can tell your problems. The physical and emotional effect of long-lasting second-hand exposure to traumatic events on helping professionals is a continuing focus of research (BellandEski,2016). officers really lack those close people who they can tell them problems that they face at work and be able to get help. Harpold and Feemster (2012) and Violantiet al., (2011) supports the findings on the premise of the need for continued research in the area of the effect of long-term exposure to violence. Police officers when at work they really feel tense or ore tight. This can be because of the hard work that they do and sometimes dangerous. According to Garner (2008), police officers are exposed to intense situations that may cause emotional exhaustion and psychological distress (Alexander, Walker, Innesand Irving, 2013). Police officers when at work they really feel frustrated and angry. This can be because of the hard work that they do and sometimes dangerous make them feel very frustrated. These statistics revealed that police brutality ranks among the highest complaints for police officers. Furthermore, a leading emotional cause of violent behavior is an individual's inability to effectively process anger and aggression (Davey, Obst, Sheehan,2011). Police officers feel under pressure due to the kind of work they are doing. According to Executive, (2016) police officers will become unstable, fragile, and vulnerable to the traumatic frustration of destructive relationships and self-image due to bad working condition and lack of close trustworthy friend. A lot of aspects upset police officers. This can be because of the hard work that they do and sometimes dangerous works. It is reasonable to conclude that exposure to violence, death, and serious injuries are unwritten job descriptors of the police occupation. Evans, and Coman, (2014) suggests this type of exposure can haunt police officers for their entire life.

\section{Conclusion}

Police officers fully understand the risks associated with their work. Police officers have accepted that most of the people they meet are sometime dangerous and make them worried of their own life. Police men when on duties are sometimes worried as they meet different people who are dangerous and this stresses them up. Police officers do really get stressed up of being complimented as most of them try to work hard but sometimes it is not as hard as it is supposed to be thus, they are worries if one of their fellow police officer compliments them as underperformance which will somehow show a bad image on the CV and daily routines. Some of the assignment or jobs that they practice are difficult and sometimes dangerous however they encourage themselves to do it for more compliment. Police officer performs are more likely difficult and sometimes dangerous for them to perform.

Police officers sometimes get blames despite of hard working especially when thing don't go the right way. Police supervisor act in a way that is not so friendly to other supervisors as they sometimes have dispute with someone else. Sometimes chief officers act in a way which is not so friendly to other as they sometimes have dispute with someone else in the force which this cause worries to other police officers. Police man needs people close to them because most of the times they work in hard environment which makes them feel tense. Police man really works in hard environment which makes them feel so frustrated and even angry. They also need comforting environment as they are working in an upsetting environment.

\section{Study Recommendations}

In light of the above findings and the conclusion drawn, the following recommendations are put forward to improve and prevent police officers from committing suicide: Since they work in a dangerous job and they have much chances of getting hurt, it is recommended that the government should consider their problems and priorities for them to work with full of passions despite the danger of the work. The study also concluded that police officers do receive blames when things go wrong and sometimes, they are getting compliments of underperformance, therefore the study recommends that they should also receive compliments when they perform a great job but also reward them.

It is recommended that the government should train police officers, chief officers but also the supervisors on how to handle matters in their duties but also on how to handle problems in order to reduce stress between each other. The study further recommends that police departments should at least arrange on how to provide mentors to their police officer. The police departments should sometimes consider the well-being of their police by at least providing seminars and trainings on self-protection especially when working under dangerous situations. 


\section{Areas for Further Research}

This study aimed at determining the effect of stress and age on decision to commit suicide among male police officers in Tabora. The study recommends similar study to be conducted in other regions in Tanzania. Furthermore, this was a quantitative research study therefore real feelings of the respondents were limited to the closed ended responses; therefore, future studies need to focus on examining the effects of the same variables but using a qualitative research design. Also, similar study can be conducted to cover more than a single region to see whether similar finding can be generated.

\section{References}

i. Alexander, D. A., Walker, L. D., Innes, G. and Irving, B. L. (2013) Police stress at work. London: The Police Foundation.

ii. Alexander, D., Walker, L., Innes, G., and Irving, B. (2014) Police stress at work. UK: Police Foundation.

iii. Anderson G. S, Litzenberger R. and Plecas D. (2002). Physical evidence of police officer stress. Policing. 25(2): 399420. doi:10.1108/13639510210429437

iv. Anshel, M. H. (2000) A conceptual model and implications for coping with stressful events in police work. Crim Justice Behav. 27(3):375-400.

v. Ballard, D., and McGlone, M. (2017) Work pressures: new agendas in communication. New York: Routledge.

vi. Bell, S. and Eski, Y. (2016) 'Break a leg- its all in the mind': police officers' attitudes towards colleagues with mental health issues. Policing. 10:1-7.

vii. Brough, P., and Biggs, A (2010) Occupational stress in police and prison staff. In: The Cambridge handbook of forensic psychology. Edited by Brown, J. M., and Campbell, E. A. New York: Cambridge University Press; 707-717.

viii. Brown, J. M., and Campbell, E. A. (2010) Sources of occupational stress in the police. Work Stress. 4(4):305-18.

ix. Bryman, A, and Bell, E. (2015). Business research methods. New York: Oxford university press Inc., 808 pp

x. Burns, R. B. and Burns, R. A. (2012). Business research methods and statistics using spss (4thed). Singapore: Sage publications -Pasificpte Ltd., 544pp.

xi. Cherry, N. M., Chen, Y., and McDonald. J. C. (2016) Reported incidenc and precipitating factors of work-related stress and mental ill-health in the United Kingdom (1996-2001). Occupational Medical. 56:414-421.

xii. Cooper, D. R. and Schindler, P. S. (2011). Business Research Methods (11th ed.). New York: McGraw-Hill/Irwin. 692 pp.

xiii. Crank, J., Cullberton, R., Hewit, J., and Regoli, B. (2015) An assessment of work stress among police executives. Journal of Criminal Justice. 21:313-224.

xiv. Cronbach, L. J. (1951). Coefficient Alpha and the Internal Structure of Tests. Psychometrika, 16297-334. doi:10.1007/BF02310555.

xv. Davey, J. D., Obst, P. L., Sheehan, M. C. (2011) Demographic and workplace characteristic which add to the prediction of stress and job satisfaction within the police workplace. Journal Police Criminal Psychology. 16(1):2939.

xvi. Deschamps, F., Paganon-Badinier, I., Marchandm A-C, Merle, C. (2003) Sources and assessment of occupational stress in the police. Journal Occupational Health. 45(6):358-64.

xvii. Evans, B. J., and Coman, G. J. (2014) General versus specific measures of occupational stress: an Australian police survey. Stress Medical. 9(1):11-20.

xviii. Executive, H. S. (2016) Work related stress, anxiety and depression statistics in Great Britain. Suffolk: Health and Safety Executive; 20pp.

xix. Franklin. J. C., Ribeiro, J. D., Fox K. R., Bentley, K. H., Kleiman, E. M., Huang, X., Musacchio, K. M., Jaroszewski, A. C., Chang, B. P. and Nock, M. K. (2017) Risk Factors for Suicidal Thoughts and Behaviors: A Meta-Analysis of 50 Years of Research. Psychological Bulletin, 143(2): 187-232

xx. Galanis, P., Fragkou, D., Kaitelidou, D., Kalokairinou, A., and Katsoulas, T. A. (2019) Risk factors for occupational stress among Greek police officers. Policing: An International journal. 42(4):506-519.

xxi. Garbarino, S., Guglielmi, O., Puntoni, M., Bragazzi, N. L. and Magnavita, N. (2019) Sleep quality among police officers: implications and insights from a systematic review and meta-analysis of the literature. International Journal of Environmental Research Public Health. 16(5):885-894.

xxii. Gershon, R. R. M, Barocas, B., Canton, A. N., Xianbin, L. and Vlahov, D. (2008) Mental, physical, and behavioural outcomes associated with perceived work stress in police officers. Criminal Justice Behaviour36(3):275-289. doi:10.1177/ 0093854808330015

xxiii. Gershon, R. R. M., Lin, S. and Li, X. (2002) Work stress in aging police officers. Journal of Occupational Environment Medical. 44(2):160-167. doi: 10.1097/00043764-200202000-00011

xxiv. Harpold, J. A., \&Feemster, S. L. (2012). Negative influences of police stress. The FBI Law enforcement Bulletin, 71, 1-7.

xxv. Harvey, S. B., Modini, M., Joyce, S., Milligan-Saville, J. S., Tan, L., Mykletun, A., Bryant, R. A., Christensen, H. and Mitchell, P. B. (2017) Can work make you mentally ill? A systematic meta-review of work-related risk factors for common mental health problems. Occupational Environmental Medicine.74(4):301-10.

xxvi. Health and Safety Executive (HSE) (2008) Striking the balance between operational and health and safety duties in the police service. Suffolk: Health and Safety Executive. 
xxvii. Hirsch, J. K., Rabon, J. K., Reynolds, E. E., Barton, A. L. and Chang, E. C. (2017). Perceived Stress and Suicidal Behaviors in College Students: Conditional Indirect Effects of Depressive Symptoms and Mental Health Stigma. Stigma and Health 8(1): 1-9.

xxviii. Husain, W. (2014) The levels of depression, anxiety and stress in police officers. Academic Research International. $5(4): 458-465$.

xxix. ICMJE ICoMJEI. (2015) Recommendations on the conduct, reporting, editing and publication of scholarly work in medical journals. USA: International Committee of Medical Journal Editors. 3(4): 478-487

xxx. Jetelina, K. K., Beauchamp, A. M., Reingle, A., Gonzalez, J. M., Molsberry, R. J., Bishopp, S. A. and Lee, S. C. (2020) Cumulative, high-stress calls impacting adverse events among law enforcement and the public. BMC Public Health. 20(1):1137. doi: 10.1186/s12889-020-09219-x

xxxi. Kapade-Nikam, P., and Shaikh, M. (2014) Occupational stress, burnout and coping in police personnel: findings from a systematic review. Am International journal of Research Humanty Arts Social Science. 14(377):144-148.

xxxii. Karmakar, S. (2014) Suicide - is it a moral crime? International Journal of Social Science \& Interdisciplinary Research 3 (7): 185-195

xxxiii. Kenwright, D. (2008) Police Stress: An Examination of the Effects of Stress and Coping Strategies. East Tennessee State University, 75pp.

xxxiv. Kim, J. L., Wells, W., Vardalis, J. J., Johnson, S. K., and Lim, H. (2016) Gender difference in occupational stress: a study of the south Korean National Police Agency. International Journal of Law Crime Justice. 44:163-82.

xxxv. Kirkcaldy, B., Cooper, C. L., and Ruffalo, P. (2015) Work stress and health in a sample of U.S. police. Psychology Rep. 76(2):700-702.

xxxvi. Komarovskaya, I., Maguen, S. and McCaslin, S. E. (2011) The impact of killing and injuring others on mental health symptoms among police officers. Journal of Psychiatr Research. 45(10):1332-1336. doi: 10.1016/j.jpsychires.2011.05.004

xxxvii. Kop, N., Euwema, M., Schaufeli, W. and Burnout, L. (2016) job stress and violent behaviour among Dutch police officers. Work Stress. 13(4):326-340.

xxxviii. Liberman, A. M., Best, S. R., Metzler, T. J., Fagan, J. A, Weiss, D. S., Marmar, C. R. and Routine, (2002) Occupational stress and psychological distress in police. Policing. 25(2):421-441. doi:10.1108/13639510210429446

xxxix. Liberman, A. M., Best, S. R., Metzler, T. J., Fagan, J. A., Weiss, D. S, and Marmar, C. R. (2002) Routine occupational stress and psychological distress in police. Policing: An International Journal Police Strategy Management. 25(2):421-439.

xl. Luceño-Moreno, L., García-Albuerne, Y., Talavera-Velasco, B., and Martín-García, J. (2016) Stress in Spanish police force depending on occupational rank, sex, age and work-shift.Psicothema. 28(4):389-393.

xli. Maguen, S., Metzler, T. J. and McCaslin, S. E. (2009) Routine work environment stress and PTSD symptoms in police officers. Journal of Nerv Mental Disorder 197(10):754-760. doi:10.1097/NMD.0b013e3181b975f8

xlii. Marchand, A., and Durand, P. (2011) Psychological distress, depression, and burnout: similar contribution of the job demand-control and job-demand-controlsupport models. Journal of Occupation Environment Medical. 53(2):185-189.

xliii. McCafferty, F. l., and McCafferty, M. A. (2012) Stress and suicide in police officers: paradigm of occupational stress. South Medical Journal. 85(3):233-243.

xliv. Moher, D., Liberati, A., Fau - Tetzlaff, J., Tetzlaff, J., Fau - Altman, D. G., and Altman, D. G. (2015) Preferred reporting items for systematic reviews and meta-analyses: the PRISMA statement; 1539-3704. (Electronic)

xlv. Office for National Statistics Report (ONS) (2014) Sickness absence on the labour market, February 2014. In.: Office for National Statistics (ONS); Available from:

https://www.ons.gov.uk/employmentandlabourmarket/peopleinwork/labourproductivity/articles/sicknessabse nceinthelabourmarket/2014-02-25.

xlvi. Officer Suicide Statistics (2019). Accessed September 9, 2020.https://bluehelp.org/resources/statistics/

xlvii. Oweke, J. A., Muola, J., and Ngumi, O. (2014) Causes of occupational stress in relation to level of occupational stress among police constables in Kisumu County, Kenya. Journal Humanity Social Science. 19(11):13-20.

xlviii. Purba, A. and Demou, E. (2019) The relationship between organizational stressors and mental wellbeing within police officers: a systematic review. BMC Public Health 1(9):1-12

xlix. Radhakrishnan, R. and Andrade, C. (2012) Suicide: An Indian perspective. Indian Journal of Psychiatry 54(4): 304319

l. Ryu G. W., Yang, Y. S., and Choi, M. (2020) Mediating role of coping style on the relationship between job stress and subjective well-being among Korean police officers. BMC Public Health 20(47): 1-8

li. Sekaran, U. (2010). Research Methods for business: A skill building approach (5th ed.). USA: John Wiley \& Sons Publisher.

lii. Song, F., Parekh, S., Hooper, L., Loke, Y. K., and Ryder, J. (2010) Dissemination and publication of research findings: an updated review of related biases. Health Technology Assess.14(8):234-240.

liii. Violanti J. M., Fekedulegn D. and Hartley T. A. (2016) Highly rated and most frequent stressors among police officers: gender differences. Am Journal of Criminal Justice 41(4):645-662. doi:10.1007/s12103-016-9342-X

liv. Violanti, J. M., Gu, J. K., Charles, L. E., Fekedulegn, D., Andrew, M. E. and Burchfiel, C. M. (2011) Is suicide higher among separated/ retired police officers? an epidemiological investigation. International Journal of Emergency Mental Health.13(4):221-228. 
lv. Violanti, J. M., Gu, M. K., Charles, L. E., Fekedulegn, D., Andrew, M. E., Burchfiel, C. M. (2011) Is Suicide Higher Among Separated/Retired Police Officers? An Epidemiological Investigation. International Journal of Emergency Mental Health. 13(4): 221-228

lvi. Zhao J. S, He N. and Lovrich N. (2002) Predicting five dimensions of police officer stress: looking more deeply into organizational settings for sources of police stress. Police Quarterly. 5(1):43-62. doi:10.1177/ 109861110200500103 